\title{
THE OCCURRENCE OF OBESITY AMONG STUDENT AT ELEMENTARY SCHOOL LAMPUNG-INDONESIA
}

\author{
Linawati Novikasari' ${ }^{1}$, Analia Kunang ${ }^{2}$, Vierto Irennius Girsang ${ }^{3}$
}

\author{
1 Lecturer in Nursing Study Program, Faculty of Medicine, Malahayati University Bandar Lampung, Indonesia \\ Email: lina.novika@malahayati.ac.id \\ 2 Lecturer in Midwifery Study Program, Institute of Health Sciences (STIKes) Muhammadiyah Pringsewu \\ Lampung, Indonesia. Email :a_kunang@yahoo.com \\ ${ }^{3}$ Lecturer in Public Health Study Program, Faculty of Pharmacy And Health Sciences, Sari Mutiara Indonesia \\ University Medan Email : iren_ljc@yahoo.com
}

\begin{abstract}
Background: Fast food is one that causes the risk of obesity and cause health problems. Nowadays, the occurrence of obesity in children tends to increase, and many other factors that can make obesity in children.

Purpose: Knowing that factors associated with occurrence of obesity among student in Elementary School (Sekolah Dasar Negeri 2) Labuhan Bandar Lampung 2018

Methods: This research was quantitative with cross sectional approach. Population in this research is all student at Elementary School (Sekolah Dasar Negeri 2) Labuhan Dalam Bandar Lampung with the sample of 63 respondents (simple random sampling).

Results: Finding, genetic factor were $33(52,4 \%)$ respondents with $p$-value 0,001 , food intake factor $35(55,6 \%)$ respondent with $p$-value 0,010 and physical activity factor $32(50,8 \%)$ respondent with $p$-value 0,007 .

Conclusion: There is a relationship between genetic factors, food intake factor and physical activity factor with the occurrence of obesity among student in Elementary School (Sekolah Dasar Negeri 2) Labuhan Bandar Lampung 2018. Suggestion, this research could be used as base data, also need to do another research with number of respondent and different method. School management to report to public health services (Puskesmas) to provide nutritionist to give health education to student about obesity.
\end{abstract}

\section{Keywords: Student, obesity, elementary school, genetic, food intake, physical activity}

\section{INTRODUCTION}

In elementary school-age children where at this time they experience growth and have the characteristics of starting to want to try to develop independence and determine their own desires. In elementary school-children is a period of childhood obtaining knowledge bases for successful adjustment to adult life and acquiring certain skills. At this age, children spend more time at school activities with various activities in the school that are quite dense so that an increase in appetite naturally (Misnadiarly, 2016).

School-age children are already good at determining the foods they like because they are familiar with the environment, usually children like instant food which contains lots of carbohydrates and vitamins as flavoring. Eating habits due to eating fast food tend to be low in fiber, low in vitamins and minerals, but high in calories, high in fat and high in sodium salt cause children to become obese. According to WHO (2013) obesity is a condition of abnormalities or excess fat accumulation in adipose tissue. Obesity is not only a condition with the amount of excess fat stores, but also the distribution of fat throughout the body. Fat distribution can increase the risk associated with various degenerative diseases (Sudargo, 2014).

Obesity has an impact on child development, especially in psychosocial aspects; boys and girls with obesity feel themselves different from people in general because of being overweight. Obesity also influences a child's psychological factors which create a feeling of lack of confidence, depression, and passivity because they are often not involved in activities carried out by peers. This psychiatric disorder can aggravate obesity in children when children vent stress experienced to food, while obesity can also have a negative impact on children's health status one of which is experiencing hypertension, coronary heart disease, shortness of breath, gallstones and even death (Ratu, 2014).

There are two terms in gaining weight, namely obesity and overweight, the term is often used to express the existence of being overweight. 
Overweight (over nutrition) that is overweight 10\% of normal body weight and obesity (overweight) that is overweight $20 \%$ of normal body weight. Clinically a person is declared obese if there is an excess of $15 \%$ or more of his ideal body weight (WHO, 2013).

Obesity is an imbalance between the amounts of food that enters compared to the expenditure of energy by the body. Obesity is overweight that exceeds normal weight. Children who are overweight are caused by excessive accumulation of body fat. While overweight is overweight compared to the ideal body weight (Sudargo, 2014).

According to the World Health Organization (WHO) in 2015 the prevalence of overweight and obesity in school-aged children reached $63 \%$, while in 2016 it increased to reach $66 \%$, this was due to $20 \%$ caused by excessive dietary patterns, $15 \%$ due to genetic factors, $9 \%$ are caused by food availability factors, $8 \%$ are caused by lack of physical activity and $6 \%$ are caused by food regulation habits (WHO, 2016).

In Indonesia the prevalence of overweight and obesity from Basic Health Research in the guidelines for prevention and control of obesity and obesity in children in 2016 shows the prevalence of obesity and obesity in children $7-12$ years at $9.2 \%$. There are eleven provinces that have carried out basic health research in 2010; Aceh (11.6), North Sumatra $(10.5 \%)$, South Sumatra $(11.4 \%)$, Riau (10.9\%), Lampung (11, 6\%), Riau Islands (9.7\%), Jakarta (12.8\%), Central Java (10.9\%), East Java $(12.4 \%)$, Southeast Sulawesi (14.7\%, West Papua $(14.4 \%)$ the results of research in several cities showed an increase in overweight obesity and in Indonesia is very worrying, this occurs due to low public awareness in educating their children to live healthier by fulfilling fiber needs, and avoid foods that are high in calories an imbalance of excessive food consumption and poor dietary arrangements are the main factors that cause obesity rates in children (Ministry of Health Republic of Indonesia, 2016).

Based on data on the occurrence of obesity in school children in Lampung Province, in 2014 obesity rates in school children reached $27 \%$, in 2015 reached $33 \%$ and in 2016 reached $37 \%$, based on the results of research conducted by health service officials, said that on average school children are obese due to food factors, physical activity and genetic factors (Dinas Kesehatan Provinsi Lampung, 2015).

According to data base in Lampung Province in 2015, the primary school that has the highest obesity rate is elementary school student (Sekolah Dasar Negeri) 3 Metro City, with 135 children out of 320 children. This is estimated to be increasing in 2020 due to the lack of health education about nutritional intake for children (Dinas Kesehatan Province Lampung, 2015).

There are two factors that can cause obesity, among other factors, directly and indirectly. Factors directly include genetic, hormonal, drugs, food intake and physical activity, while factors indirectly include knowledge about nutrition, knowledge of eating (overeating, snacking on snacks, eating hastily, and wrongly choose and process food) (Sulistyoningsih, 2012).

The occurrence of obesity in Elementary School student at Pekanbaru in 2013, stated that the statistical test results were obtained $p$-value $<0.05(p=0.044)$ meaning there was a significant relationship between history exclusive breastfeeding with the occurrence of obesity. The results of statistical tests obtained $p$-value $<0.05$ ( $p$ $=0.037$ ) means that there is a significant relationship between the duration of breastfeeding and the occurrence of obesity. The results of statistical tests obtained $p$-value $<0.05(p=0.018)$ means that there is a significant relationship between the frequency of fast food consumption and the occurrence of obesity (Sartika, 2013).

Based on presurvey data on December 2, 2017 At elementary school student (Sekolah Dasar Negeri) 1, 2 and 3 Labuhan in Bandar Lampung about the occurrence of obesity in children, data were obtained that in 2017 at elementary school student (Sekolah Dasar Negeri) 1 Labuhan in Bandar Lampung, the occurrence of obesity in children was 22 students of 240 students. In elementary school student (Sekolah Dasar Negeri) 2 Labuhan in Bandar Lampung there were 36 students of 237 students, while in elementary school student (Sekolah Dasar Negeri) 3 Labuhan in Bandar Lampung there were 19 children of 232 students. Of the three elementary schools in Labuhan Dalam, only elementary school student

Linawati Novikasari' Lecturer in Nursing Study Program, Faculty of Medicine, Malahayati University Bandar Lampung, Indonesia Email: lina.novika@malahayati.ac.id

Analia Kunang ${ }^{2}$ Lecturer in Midwifery Study Program, Institute of Health Sciences (STIKes) Muhammadiyah Pringsewu Lampung, Indonesia. Email :a_kunang@yahoo.com

Vierto Irennius Girsang ${ }^{3}$ Lecturer in Public Health Study Program, Faculty of Pharmacy And Health Sciences, Sari Mutiara Indonesia University Medan. Email : iren_ljc@yahoo.com 
(Sekolah Dasar Negeri) 2 Labuhan Dalam with obesityoccurrenceis quite high. In 2017 the number of children in elementary school student (Sekolah Dasar Negeri) 2 Labuhan in 220 children, with the occurrence of obesity reaching $30 \%$. So that researchers are interested in researching in elementary school student (Sekolah Dasar Negeri) 2 Labuhan Dalam Bandar Lampung.

After the researchers found out the number of obesity in school children, researchers conducted direct observations on grade 4 in elementary school student (Sekolah Dasar Negeri) 2 Labuhan in Bandar Lampung, in 40 students found that 12 students were obese, based on indepth interview data it was found that 2 students $(16.7 \%$ ) Obese due to heredity, 2 students $(16.7 \%)$ had excessive food intake, 4 students $(33.3 \%)$ unlike exercise, and 4 students $(33.3 \%)$ liked to have a snack at night.
In accordance with the description above, researchers are interested in conducting research on obesity in children. For that the title that the researchers took in this study was "factors related to the problem of obesity in school-age children in (Sekolah Dasar Negeri) Labuhan in Bandar Lampung in 2017".

\section{RESEARCH METHODS}

Types of quantitative, analytical research with Cross Sectional approach. The population consisted of all children at (Sekolah Dasar Negeri) Labuhan in Bandar Lampung classes 3,4,5 and 6 which amounted to 185 students, with a sample of 63 respondents with simple random sampling. Data taken with questionnaire sheets, analysis was carried out by univariate (frequency distribution) and bivariate (chi-square).

\section{RESEARCH RESULTS}

Table 1. Frequency Distribution of Genetic Factors

\begin{tabular}{lcc}
\hline Genetic & Frequency & Percentage (\%) \\
\hline Have a genetic component & 30 & 47.6 \\
Have not a genetic component & 33 & 52.4 \\
Total & 63 & 100.0 \\
\hline
\end{tabular}

Table 2. Distribution of Frequency Factors of Food Intake

\begin{tabular}{lll}
\hline Feed Intake & Frequency & Percentage (\%) \\
\hline Good & 28 & 44.4 \\
Fair & 35 & 55.6 \\
Total & 63 & 100.0 \\
\hline
\end{tabular}

Table 3. Frequency Distribution of Physical Activity

\begin{tabular}{lll}
\hline Physical Activity & Frequency & Percentage (\%) \\
\hline Good & 32 & 50.8 \\
Bad & 31 & 49.2 \\
Total & $\mathbf{6 3}$ & $\mathbf{1 0 0 . 0}$ \\
\hline
\end{tabular}

Linawati Novikasari' Lecturer in Nursing Study Program, Faculty of Medicine, Malahayati University Bandar Lampung, Indonesia Email: lina.novika@malahayati.ac.id

Analia Kunang ${ }^{2}$ Lecturer in Midwifery Study Program, Institute of Health Sciences (STIKes) Muhammadiyah Pringsewu Lampung, Indonesia. Email :a_kunang@yahoo.com

Vierto Irennius Girsang ${ }^{3}$ Lecturer in Public Health Study Program, Faculty of Pharmacy And Health Sciences, Sari

Mutiara Indonesia University Medan. Email : iren_ljc@yahoo.com 
Malahayati International Journal of Nursing and Health Science, Volume 01, No.1, March 2018: 17-25

THE OCCURRENCE OF OBESITY AMONG STUDENT AT ELEMENTARY SCHOOL LAMPUNG-INDONESIA

Table 4. Frequency Distribution of the Occurence of Obesity

\begin{tabular}{lll}
\hline Body Weight & Frequency & Percentage (\%) \\
\hline Normal & 28 & 44.4 \\
Obesity & 35 & 55.6 \\
Total & $\mathbf{6 3}$ & $\mathbf{1 0 0 . 0}$ \\
\hline
\end{tabular}

Table 5. Analysis of the Relationship of Genetic with Obesity

\begin{tabular}{|c|c|c|c|c|c|c|c|c|}
\hline \multirow[t]{3}{*}{ Genetic Factors } & \multicolumn{4}{|c|}{ Obesity Occur } & \multicolumn{2}{|c|}{ Total } & \multirow[t]{3}{*}{$p$-Value } & \multirow{3}{*}{$\begin{array}{l}\text { OR } \\
\text { (Cl 95\%) }\end{array}$} \\
\hline & \multicolumn{2}{|c|}{ Without Obesity } & \multicolumn{2}{|c|}{ With Obesity } & & & & \\
\hline & $\mathrm{n}$ & $\%$ & $\mathrm{n}$ & $\%$ & $\mathbf{N}$ & $\%$ & & \\
\hline Have a genetic Component & 6 & 20.0 & 24 & 80.0 & 30 & 100.0 & 0.001 & 0.125 \\
\hline Have not a genetic component & 22 & 66.7 & 11 & 33.3 & 33 & 100.0 & & $(0.040-0.395)$ \\
\hline Total & 28 & 44.4 & 35 & 55.6 & 63 & 100.0 & & \\
\hline
\end{tabular}

Based on table 5 it is known that, there were 30 respondents who had genetic factors, of which 6 respondents (20.0\%) experienced normal weight and 24 respondents $(80.0 \%)$ were obese, while there were 33 children who Have not a genetic component factors, where 22 respondents $(66.7 \%)$ have normal body weight and 11 respondents $(33.3 \%)$ are obese. Based on statistical tests, it is known that $p$-value is 0.001 or $p$-value $<0.05$, which means that there is a significant relationship between genetic factors and obesity occur in children. $\mathrm{OR}$ is 0.125 which means respondents who did not have genetic factors had 0.125 times greater risk of not being obese.

Table 6. Relationship Analysis of Food Intake and Obesity

\begin{tabular}{|c|c|c|c|c|c|c|c|c|}
\hline \multirow[t]{3}{*}{ Intake Factors } & \multicolumn{4}{|c|}{ Occurrence of Obesity } & \multirow{2}{*}{\multicolumn{2}{|c|}{ Total }} & \multirow[t]{3}{*}{ p-Value } & \multirow{3}{*}{$\begin{array}{l}\text { OR } \\
\text { (Cl 95\%) }\end{array}$} \\
\hline & \multicolumn{2}{|c|}{ Normal weight } & \multicolumn{2}{|c|}{ Obesity } & & & & \\
\hline & $n$ & $\%$ & $\mathrm{n}$ & $\%$ & $\mathbf{N}$ & $\%$ & & \\
\hline Good & 18 & 64.3 & 10 & 35.7 & 28 & 100.0 & 0.010 & 4,500 \\
\hline Fair & 10 & 28,6 & 25 & 72,4 & 35 & 100,0 & & $(1,550-13,061)$ \\
\hline Total & 28 & 44,4 & 35 & 55,6 & 63 & 100,0 & & \\
\hline
\end{tabular}

Based on table $5 \mathrm{It}$ is known that, there were 28 respondents who had good food intake factors, of which 18 respondents $(64.3 \%)$ experienced normal body weight and 10 respondents $(35.7 \%)$ were obese, while there were 35 respondents having poor food intake factor, where 10 respondents $(28.6 \%)$ had normal body weight and 25 respondents $(72.4 \%)$ were obese. Based on statistical tests, it was found that $p$-value was 0.010 or $p$-value $<0.05$, which means that there is a significant relationship between food intake factors and Occurrence of Obesity And OR value of 4,500 means that respondents who have a good food intake will have a risk of 4,500 times greater for obesity

Linawati Novikasari' Lecturer in Nursing Study Program, Faculty of Medicine, Malahayati University Bandar Lampung, Indonesia Email: lina.novika@malahayati.ac.id

Analia Kunang ${ }^{2}$ Lecturer in Midwifery Study Program, Institute of Health Sciences (STIKes) Muhammadiyah Pringsewu Lampung, Indonesia. Email :a_kunang@yahoo.com

Vierto Irennius Girsang ${ }^{3}$ Lecturer in Public Health Study Program, Faculty of Pharmacy And Health Sciences, Sari

Mutiara Indonesia University Medan. Email : iren_ljc@yahoo.com 
Malahayati International Journal of Nursing and Health Science, Volume 01, No.1, March 2018: 17-25

THE OCCURRENCE OF OBESITY AMONG STUDENT AT ELEMENTARY SCHOOL LAMPUNG-INDONESIA

Table 7. Relationship between Physical Activity Factors and Occurrence of Obesity

\begin{tabular}{|c|c|c|c|c|c|c|c|c|}
\hline \multirow[t]{3}{*}{ Physical Activity Factors } & \multicolumn{4}{|c|}{ Occurrence of Obesity } & \multirow{2}{*}{\multicolumn{2}{|c|}{ Total }} & \multirow[t]{3}{*}{ P-Value } & \multirow{3}{*}{$\begin{array}{l}\text { OR } \\
\text { (CI 95\%) }\end{array}$} \\
\hline & \multicolumn{2}{|c|}{ Normal weight } & \multicolumn{2}{|c|}{ Obesity } & & & & \\
\hline & $n$ & $\%$ & $n$ & $\%$ & $\mathrm{~N}$ & $\%$ & & \\
\hline Good & 20 & 62.5 & 12 & 37.5 & 32 & 100.0 & 0.007 & 4.792 \\
\hline Bad & 8 & 25.8 & 23 & 74.2 & 31 & 100.0 & & (1.633 to 14.064$)$ \\
\hline Total & 28 & 44.4 & 35 & 55.6 & 63 & 100.0 & & \\
\hline
\end{tabular}

Based on table 6 it is known that there were 32 respondents who had good physical activity factors, where 20 respondents $(62.5 \%)$ experienced normal body weight and 12 respondents $(37.5 \%)$ were obese, while there were 31 respondents who had bad physical activity factors, where 8 respondents $(25.8 \%)$ had normal body weight and 23 respondents $(74.2 \%)$ were obese. Based on statistical tests, it is known that $p$ value 0.007 or $p$-value $<0.05$, which means that there is a significant relationship between factors of physical activity and the Occurrence of Obesity and $\mathrm{OR}$ value is 4.792 meaning that respondents who have a bad physical activity factor will have a risk of 4.792 times greater for obesity.

\section{DISCUSSION \\ Genetic Factors}

Based on table 4.1, it is known that in SD 2 Labuhan in Bandar Lampung in 2017, most respondents had genetic factors totaling 24 respondents $(80.0 \%)$. In theory, on genetic factors, obesity can be reduced from generation to generation in a family. Fat parents tend to have fat children too. The influence of parents is an important risk factor for increasing weight and obesity in children. Although the influence of genetic factors, actually was unclear as the cause of obesity. However, there is some evidence to suggest that genetic factors are a strengthening factor in the occurrence of obesity. According to the study, children from parents who have normal weight turned out to have a $10 \%$ risk of obesity. If one of his parents suffers from obesity, then the risk increases to $40-50 \%$. And if both parents suffer from obesity, the risk of heredity becomes 70-80\% (Purwanti, 2011).
According to a previous study entitled Factors Associated with Obesity Events in Class VII and VIII Students / I at the 34 Medan Middle School in 2014. The results of the study showed that based on family history in Medan 34 Public Middle School in 2014 there were 32 people (32\%) have genetic factors related to the occurrence of obesity. Based on the results of the above research, most respondents have genetic factors totaling 24 respondents $(80.0 \%)$ out of a total of 63 respondents and this study was semelar previous studi that many respondents who are obese due to genetic factors. With the condition that one parent suffers from obesity, the risk for obesity also increases even if both parents suffer from obesity, the risk of obesity is increasing. This can be caused by an excessive urge to eat, often related to the beliefs of parents where obese children are healthy children. To reduce the risk of obesity in children, parents can control children's eating habits, physical activity, and availability of food (Afrienny \& Lubis, 2015).

\section{Food Intake Factors}

Food intake is the amount of food a person consumes. Foods with high energy density (lots of fat and added sugar and less fiber) also contribute to this positive energy balance. According to the theory, there are three things that affect food intake, namely eating habits, knowledge, and food availability in family. Eating habits are related to food according to local traditions, including things about how food is obtained, what is chosen, how to prepare, who eats, and how much is eaten (Susilowati, 2016).

According the previous studi obesity is only possible if there is excess food in the body, especially food sources of energy (Sartika, 2013).

Linawati Novikasari' Lecturer in Nursing Study Program, Faculty of Medicine, Malahayati University Bandar Lampung, Indonesia Email: lina.novika@malahayati.ac.id

Analia Kunang ${ }^{2}$ Lecturer in Midwifery Study Program, Institute of Health Sciences (STIKes) Muhammadiyah Pringsewu Lampung, Indonesia. Email :a_kunang@yahoo.com

Vierto Irennius Girsang ${ }^{3}$ Lecturer in Public Health Study Program, Faculty of Pharmacy And Health Sciences, Sari

Mutiara Indonesia University Medan. Email : iren_ljc@yahoo.com 
Excess food is often not realized by sufferers of obesity. In addition, because the availability of food makes obese sufferers sometimes forget to regulate food intake and diet. Most of the school children in this study prefer to consume fast food or fast foods compared to traditional food or bring their own lunch from home. This is due to various reasons such as tastes that are better, easier to obtain and practical. Besides the influence of the environment that causes schoolchildren to choose types fast food than traditional foods. More food intake will cause fat accumulation in the body and have an impact on the occurrence of obesity if it is not balanced with physical activity carried out.

\section{Physical Activity Factors}

Most respondents did not have good activities totaling 32 respondents $(50.8 \%)$. In theory, obesity can not only occur due to over eating, but also due to reduced physical activity resulting in excess energy. Some things that affect the reduction in physical activity include the presence of various facilities that provide various facilities that cause decreased physical activity. Another factor is the existence of technological advances in various fields of life that encourage people to take a life that does not require heavy physical labor (Gunarsa, 2010).

According to Weni Research, (2015) about the factors that influence theoccurrenceof obesity in adolescents. The results of the study showed that based on non-active physical activity there were 41 people $(56.9 \%)$ who had physical activity factors related to the occurrence of obesity. Based on the results of the study, most respondents did not do good activities totaling 32 respondents $(50.8 \%)$. This shows that there are still many respondents who are obese due to lack of physical activity undertaken. This research is in line with the research conducted by the reduction in physical activity, among others, the existence of various facilities that provide various facilities that cause decreased physical activity. Another factor is the existence of technological advances in various fields of life that encourage people to live a life that does not require heavy physical work (Weni, 2015).

The results of the study that there is a relationship between lack of physical activity and the occurrence of obesity. From the results of the study, it was found that there were some respondents who lacked good activities such as exercising every morning for at least 30 minutes. However, the number of school children who after watching live watching television, lying down playing mobile phones, playing play station, playing computers and the internet even went straight to bed. This can cause accumulation of fat in the body due to lack of physical activity carried out.

\section{The Occurence of Obesity}

Most respondents were obese, amounting to 35 respondents $(55.6 \%)$. Obesity is the excess fat in the body, which is generally accumulated in subcutaneous tissue (under the skin), around the organs and sometimes expansion into the tissues of the organs. Based on the results of this study, most respondents were obese, amounting to 35 respondents $(55.6 \%)$. This obesity shows an imbalance between height and weight due to fat tissue in the body so that excess weight exceeds the ideal size. The occurrence of obesity is more determined by too much eating, too little activity or physical exercise, or both (Misnadiarly, 2016).

Obesity in adolescents is important to note because adolescents who are obese are $80 \%$ at risk for obesity as well as adults. In addition, there is an increase in obese adolescents who are diagnosed with disease conditions commonly experienced by adults, such as type 2 diabetes and hypertension. Obese adolescents throughout their lives are also at higher risk of suffering from a number of serious health problems, such as heart disease, stroke, diabetes, asthma. In addition, psychological and social conditions in adolescents will increase because they will be rejected by friends and ostracized because of their weight.

\section{Bivariate Analysis \\ Relation of Genetic Factors to Obesity in Children}

There were 30 respondents who had genetic factors, of which 6 respondents $(20.0 \%)$ experienced normal weight and 24 respondents (80.0\%) were obese, while there were 33 children who do not have genetic factors, where 22 respondents $(66.7 \%)$ have normal body weight and 11 respondents (33.3\%) are obese. Based on statistical tests, it is known that $p$-value is 0.001 or

Linawati Novikasari' Lecturer in Nursing Study Program, Faculty of Medicine, Malahayati University Bandar Lampung, Indonesia Email: lina.novika@malahayati.ac.id

Analia Kunang ${ }^{2}$ Lecturer in Midwifery Study Program, Institute of Health Sciences (STIKes) Muhammadiyah Pringsewu Lampung, Indonesia. Email :a_kunang@yahoo.com

Vierto Irennius Girsang ${ }^{3}$ Lecturer in Public Health Study Program, Faculty of Pharmacy And Health Sciences, Sari

Mutiara Indonesia University Medan. Email : iren_ljc@yahoo.com 
$p$-value $<0.05$, which means that there is a significant relationship between genetic factors and the occurrence of obesity and OR was 0.125 which means respondents who do not have genetic factors will have a risk of 0.125 times greater to be obese.

Genetic factors are hereditary factors originating from their parents. The effect of these factors is actually not too clear as the cause of obesity. However, there is some evidence to suggest that genetic factors are a strengthening factor in the occurrence of obesity. According to the study, children from parents who have normal weight turned out to have a $10 \%$ risk of obesity. If one of his parents suffers from obesity, then the risk increases to $40-50 \%$. And if both parents suffer from obesity, the risk of heredity becomes $70-80 \%$ (Purwanty, 2011). There is a relationship between over eating and obesity with a $p$-value of 0,000 . There is a relationship between factors of physical activity with the occurrence of obesity with a p-value of 0.002 and there is a relationship between family history and the occurrence of obesity with a $p$-value of 0.001 (Afrienny \& Lubis, 2015). Based on the results of research conducted by researchers, that most children are obese due to genetic factors. But the phenomenon when researchers conduct research, there are some children who do not have genetic factors but are obese, this is because there are other factors that affect obese, one of them is a less regular diet and excessive eating and stating that there is a relationship between lifestyle factors and the occurrence of obesity

\section{Relationship Factors Physical Activity with Obesity in Children}

There were 32 respondents who had good physical activity factors, where 20 respondents $(62.5 \%)$ experienced normal body weight and 12 respondents $(37.5 \%)$ were obese, while there were 31 respondents who had bad physical activity factors, where 8 respondents $(25.8 \%)$ had normal body weight and 23 respondents (74.2\%) were obese. Based on statistical tests, it is known that $p$ value 0.007 or $p$-value $<0.05$, which means that there is a significant relationship between factors of physical activity and OR p-value is 4.792 meaning that respondents who have a bad physical activity factor will have a risk of 4.792 times greater for obesity.

Physical activity is physical movement carried out by the muscles of the body and its supporting system. Physical activity is any bodily movement produced by skeletal muscle that requires energy expenditure (Almatsier, 2003; Danari, Maluyu \& Onibala, 2013).

Absence of physical activity (lack of physical activity) is an independent risk factor for chronic diseases, and overall is expected to cause death globally. Physical activity is physical work that involves the body's loco motor system which is intended to carry out daily living activities, if a physical activity has a specific purpose and is carried out with certain rules systematically such as the time rule, target pulse, number of repetitions of movements and others - another is called practice. Whereas what is meant by sports is an exercise carried out by containing elements of recreation (Sartika, 2011). The effect of physical activity can be instantaneous called acute response and long-term effects due to regular and programmed training called adaptation. Including the acute response is increased frequency of heart rate, increased frequency of breathing, increased blood pressure and increased body temperature. Including adaptations include increased muscle mass, increased bone mass, increased antioxidant defense system and decreased resting heart rate. Physical activity occurs in various domains / places, for example in the workplace, while traveling, in sports-specific places, and during leisure and leisure times (Kristianti, 2002; Dwi, 2012).

Based on the results of the research conducted, most of the respondents were obese due to lack of physical activity; this was due to the lack of burning calories that were not maximal. But based on the results of the research that the researchers did, there is a phenomenon that is many children who have good physical activity, but are obese, this is due to excessive eating habits that are not balanced with physical activity, and are thought to be due to genetic factors.

\section{Relationship between Factors of Eating Intake and Obesity in Children}

There were 28 respondents who had good food intake factors, of which 18

\footnotetext{
Linawati Novikasari' Lecturer in Nursing Study Program, Faculty of Medicine, Malahayati University Bandar Lampung, Indonesia Email: lina.novika@malahayati.ac.id

Analia Kunang ${ }^{2}$ Lecturer in Midwifery Study Program, Institute of Health Sciences (STIKes) Muhammadiyah Pringsewu Lampung, Indonesia. Email :a_kunang@yahoo.com

Vierto Irennius Girsang ${ }^{3}$ Lecturer in Public Health Study Program, Faculty of Pharmacy And Health Sciences, Sari Mutiara Indonesia University Medan. Email : iren_ljc@yahoo.com
} 
respondents $(64.3 \%)$ experienced normal body weight and 10 respondents $(35.7 \%)$ were obese, while there were 35 respondents having poor food intake factor, where 10 respondents $(28.6 \%)$ had normal body weight and 25 respondents $(72.4 \%)$ were obese. Based on statistical tests, it is known that the $p$ value is 0.010 or $p$-value $<0.05$, which means there is a significant relationship between food intake factors and $O R$ value of 4,500 is obtained. it means that respondents who have poor food intake factors will have a risk of 4,500 times more likely to be obese.

Food intake is the amount of food a person consumes. Chronic excess energy intake will cause weight gain, overweight, and obesity. Foods with high energy density (lots of fat and added sugar and less fiber) also contribute to this positive energy balance. It should be believed that obesity is only possible if there is excess food in the body, especially food sources of energy. And the excess food is often not realized by obese people. There are three things that affect food intake, namely eating habits, knowledge, and food availability in the family. Eating habits are related to food according to local traditions, including things about how food is obtained, what is chosen, how to prepare, who eats, and how much is eaten (Sulistyoningsih, 2012).

Food availability also affects food intake, the better the food availability of a family, enabling the fulfillment of all nutritional needs (Sulistyoningsih, 2012). Food availability is strongly influenced by family empowerment and the use of community resources. Both of these are strongly influenced by the level of education and poverty.

Nutritional adequacy according to the Recommended dietary Allowance (RDA) in 1989 is that the amount of nutrients that must be fulfilled from food includes almost all healthy people. Adequacy of nutrition is influenced by age, gender, activity, weight, height, genetics, and the state of pregnancy and lactation. The recommended nutritional adequacy is different from nutritional needs (Damapoli, Mayulu, \& Masi, 2013).

Based on research conducted by researchers, it is known that some respondents have genetic factors, poor food intake and lack of activities carried out with the occurrence of obesity so that respondents have a greater risk of obesity, but based on the phenomenon that researchers get, there are some respondents who do not have genetic factors but still obese, this is due to other factors such as poor food intake and lack of physical activity. Conversely, respondents who have good food intake, but are still obese, this is due to other factors such as genetic factors and lack of physical activity.

Similarly, respondents who have good physical activity, but are still obese, this is due to other factors such as genetic factors and poor food intake. Obesity can also occur not only because of genetic factors and overeating, but also due to reduced physical activity resulting in excess energy.

Some things that affect the reduction in physical activity include the presence of various facilities that provide various facilities that cause decreased physical activity. Another factor is the existence of technological advances in various fields of life that encourage people to live a life that does not require heavy physical labor.

\section{CONCLUSION}

There is a relationship; genetic, physical activity factors and the occurrence of obesity.

\section{SUGGESTIONS}

It is hoped that this research can be used as the basic data for conducting research with a number of respondents and different methods, expected for teachers, administrative staff and health workers to improve the quality of health services by: Always active in providing health counseling specifically about the importance of obesity prevention behavior knowledge, so that respondents are able prevent obesity, conduct a sports program with gymnastics for children every 1 time a week, supervision of children who want to snack in the school cafeteria, provide encouragement or motivation to children about prevention of obesity through media leaflets, posters, and flipcharts. Educational Institutions can add to the literature on factors related to obesity in school-age children in the Faculty of Medicine Library Nursing Study Program which can be used

Linawati Novikasari' Lecturer in Nursing Study Program, Faculty of Medicine, Malahayati University Bandar Lampung, Indonesia Email: lina.novika@malahayati.ac.id

Analia Kunang ${ }^{2}$ Lecturer in Midwifery Study Program, Institute of Health Sciences (STIKes) Muhammadiyah Pringsewu Lampung, Indonesia. Email :a_kunang@yahoo.com

Vierto Irennius Girsang ${ }^{3}$ Lecturer in Public Health Study Program, Faculty of Pharmacy And Health Sciences, Sari

Mutiara Indonesia University Medan. Email : iren_ljc@yahoo.com 
by students as a reading. Further research regarding obesity factors, researchers are advised to discuss more deeply about the factors related to respondents' behavior about the occurrence of obesity.

\section{REFERENCES}

Afrienny, R., \& Lubis, R. (2015). Faktor-Faktor Yang Berhubungan Dengan Obesitas Pada Siswa/i Kelas VII Dan VIII Di SMP Negeri 34 Medan Tahun 2014. Gizi, Kesehatan Reproduksi dan Epidemiologi, 1(4).

Danari, A. L., Mayulu, N., \& Onibala, F. (2013). Hubungan Aktivitas Fisik dengan Kejadian Obesitas pada Anak SD di Kota Manado. Jurnal Keperawatan, 1(1).

Diarly, M. (2016). Obesitas Sebagai Faktor Risiko Beberapa Penyakit.

Dinas Kesehatan Provinsi Lampung.(2015). Data Prevalensi Kejadian Obesitas. Lampung: DinasKesehatan Lampung.

Djuanda, A., Azwar, A., Ismael, S., Almatsier, M., Setiabudi, R., \& Firmansyah, R. (2012). MIMS Indonesia Petunjuk Konsultasi (Vol. Edisi 12 2012/2013). A. Pramudianto dan Evaria, Eds.) Indonesia: Buana IImu Populer.

Damapolii, W., Mayulu, N., \& Masi, G. (2013). Hubungan Konsumsi Fastfood dengan Kejadian Obesitas pada Anak SD di Kota Manado. Jurnal Keperawatan, 1(1).

Dwi, O. W. (2012). Hubungan kebiasaan konsumsi fast food, aktivitas fisik, pola konsumsi, karakteristik remaja dan orang tua dengan indeks massa tubuh (IMT)(studi kasus pada siswa SMA Negeri 9 Semarang tahun 2012). Jurnal Kesehatan Masyarakat Universitas Diponegoro, 1(2).

Gunarsa, S. D. (2010). Dasar dan teori perkembangan anak. BPK Gunung Mulia.

\begin{abstract}
Kementerian Kesehatan Republik Indonesia.(2012). Pedoman Pencegahan Dan Penanggulangan Kegemukan Dan Obesitas Pada Anak Sekolah. Jakarta: Departemen Kesehatan.
\end{abstract}

Kementrian Kesehatan Republik Indonesia.(2016). Data Dan Informasi Profil Kesehatan Indonesia.Jakarta:

Kurdanti, W., Suryani, I., Syamsiatun, N. H., Siwi, L. P., Adityanti, M. M., Mustikaningsih, D., \& Sholihah, K. I. (2015). Faktor-faktor yang mempengaruhi kejadian obesitas pada remaja. Jurnal Gizi Klinik Indonesia, 11(4), 179190.

Sartika, Y (2013).Tentang Faktor-Faktor Yang Berhubungan Dengan Kejadian Obesitas Pada Anak Sekolah DasarDi Wilayah Kerja Puskesmas Garuda: Pekan Baru: Sumatera Utara. http.Ejurnal USU. Ac.id.Diaksespada 0911-16.

Sudargo, T., Freitag, H., Kusmayanti, N. A., \& Rosiyani, F. (2018). Pola makan dan obesitas. UGM press.

Sulistyoningsih, H. (2011). Gizi untuk kesehatan ibu dan anak. Yogyakarta: Graha IImu, 128.

Susilowati, K. (2016). Gizi dalam daur kehidupan. PT Refika Aditama: Bandung.

Wahyu, G. G. (2011). Obesitas pada anak. Bentang Pustaka.

WHO. (2013). Prevalensi Kejadian Obesitas. USA: Philadelphia.

Yuniastuti, A. (2008). Gizi Dan Kesehatan. Yogyakarta: Graha IImu.

Linawati Novikasari' Lecturer in Nursing Study Program, Faculty of Medicine, Malahayati University Bandar Lampung, Indonesia Email: lina.novika@malahayati.ac.id

Analia Kunang ${ }^{2}$ Lecturer in Midwifery Study Program, Institute of Health Sciences (STIKes) Muhammadiyah Pringsewu Lampung, Indonesia. Email :a_kunang@yahoo.com

Vierto Irennius Girsang ${ }^{3}$ Lecturer in Public Health Study Program, Faculty of Pharmacy And Health Sciences, Sari

Mutiara Indonesia University Medan. Email : iren_ljc@yahoo.com 